\title{
MECOM Positive
}

National Cancer Institute

\section{Source}

National Cancer Institute. MECOM Positive. NCI Thesaurus. Code C150599.

An indication that expression of MECOM has been detected in a sample. 